\title{
CHALLENGES OF GEOGRAPHY IN NEPAL
}

\section{Tara Prasad Awasthi ${ }^{1}$}

\begin{abstract}
Geography is the science of place and space. It focuses on mechanism of people, place and environment in general and people and their activities in particular. This paper attempts to analyze challenges of geography education in Nepal. For this, data were collected from both the primary and secondary sources through interviews, group discussion and field observation covering five schools and campuses offering geography. Knowledge of geography is necessary for each and every citizen for the national development. It requires effective geography education at various levels that introduces national territory, topography, soil, water, climate, vegetation, people, settlement, planning and resources. However, the geography education has been taught as an optional subject and it is competing with the other subjects like computer science, optional math, and economics in secondary and higher secondary levels in Nepal. As a result, there is no room for choosing geography as an optional subject to majority of students. They forced to select their least favored subject which was decided by school. Nowadays, the number of schools and students have been decreasing in geography subject at both school and university level.
\end{abstract}

Key words: Geography, curricula, policy, job market, challenges, topography

\section{Introduction}

Geography explores the relationship between the earth and its people through the study of place, space and environment. It is mechanically of place, people and the environment. Thus, geography is the science of place and space. Geographers ask where things are located on the surface of the earth, why they are located, how places differ from one another, and how people interact with the environment. Geographers also study the linkage between human activities and natural systems. They are active in the study of global warming, desertification, loss of biodiversity, climate change and flooding

1 Awasthi is a Lecturer, Department of Geography Education, Central Department of Education, Tribhuvan University,Email: star2012awasthi@gmail.com 
(http//www.esri.com, 2013). Hanson (1997) addressed the presidential speech at the Association of American Geographers (AAG) in 1991 "I was not to define geography but to stimulate people in our field to think about what geographers have contributed to the world and how geographic thinking tribute to the world and how geographic thinking has changed and might change the world (Hanson,1997). Geography has meant different things to different people at different time in different places (Livingston, 1992).

The scholars like Kant, Humboldt, Ritter, Peschele, and Ratzel had contributed to the development of scientific geography in the nineteenth century (Amatya, 1974). The majority of geographers employed environmental determinism as a guiding principle for geographic study, especially in Germany. According to Determinism, man is a passive agent, and nature is an active agent, which controls and determines the action and decision-making processes of man. The human actions can be explained as a response to the natural environment (http//www.esri.com, 2013). However, it was somewhat derailed after the contribution of French geographers. Vidal de la Blache proposed the alternative view regarding environmentalism. The concept of possibilism assumed that environment sets certain constraints or limitations, but culture is otherwise determined by social conditions. Nature provides possibilities and man utilizes them according to his culture, traditions, and levels of socioeconomic development. People are not just the products of their environment or just a pawn of the natural environment. Nature is never more than an adviser. There are not necessities, but everywhere possibilities (http// www.esri.com, 2013). Both environmental determinism and possibilism are known as the study of human-environment interactions in geographic literature. Similarly, the concept of areal differentiation has also become major geographical theme. It can be argued that environmental determinism, possibilism and areal differentiation provided both theoretical and philosophical bases for geographic analysis. However, all these themes emerging towards opposite directions and deviating from the main thrust of the development of the discipline. These inappropriate debates have not only lost the identity of geography, but also did not develop scientific methodology on time (Kitchen $\&$ Tate, 2000).

Geographers have used an interdisciplinary approach mixing of both physical and social sciences theories and philosophies in geographic research (Adhikari, 2003). For example, geographers have been employed to positivist approach for geographical studies. Like most other social science disciplines, it is dynamic and over the last few decades, changes took place in both the nature and scope of the discipline (Subedi \& Joshi, 1997). In Nepal, geography was introduced much later. The first book on geography in Nepal was published by Jaya Prithvi Bahadur Singh in 1901 (Pandey, 1998). However, the discipline became more systematic and organized only after the 
establishment of school leaving certificate examination Board and Trichandra College. At the university level, Faculties of Humanities and Social Sciences and Education have separately taught geography curricula. The first gives priority on content and the latter on both content and pedagogy (Pandey, 1998).

In spite of its development, a lot of debates and dilemma concerning on the disciplinary expectations of the society (Subedi \& Joshi, 1997) in the one hand and curricular issues like vertical linkages of courses, teaching methods and materials on the other (Panday, 1998; Jnawali 2001). The existing literature highlighted the issues and challenges of geography teaching in Nepal. Most of the studies have been pointing to the usefulness of geography discipline, not only for teaching-learning, but also in the National Planning Commission and delineation of administrative and Electoral Constituency boundaries in the past. However, various studies indicate that the importance of teaching geography at school and university level have been declining in the recent years. It can argue that the importance of geography discipline is increasing due to explore diverse physical, sociocultural, economic and environmental conditions of Nepal. Nowadays, the discipline has been misleading in various ways. Thus, requires rebuild the discipline in order to embrace relevant contents and methodologies which could be more oriented to evaluate complexities of the societies providing necessary actions (Koirala, 2008). As a result, geographers are able to compete in the fields of pedagogical and research work using new tools and techniques to fulfill emerging needs of the markets. In this context, this paper attempts to explore the challenges of geography in Nepal.

\section{Methods and Materials}

This paper is based on both primary and secondary data sources. Primary data were collected from field survey employing questionnaire survey, in-depth interview, key informant interview and group discussion. For this purpose, five campuses who taught geography subject in Kathmandu valley were purposively selected for detail study. Group discussions were organized among students and in-depth interviews were taken from geography teachers. At least one senior geography teacher from each campus was selected for key person interview. All these methods and tools support to collect information to identify the causes of declining student numbers in geography subject as compared to other subjects.

The secondary data were generated from various sources, such as archive documents of campuses, official records and reviews of books, reports, journals and internet websites. All collected data were categorized into both qualitative and quantitative (mixed) research frame and used descriptive and analytical methods for data analysis. 


\section{Results and Discussion}

Historical Development of Geography Education in Nepal: Geography as an academic field of study dates back to the beginning of the $20^{\text {th }}$ century, in Nepal; although the use of geographic ideas, concepts and geographical description of the place go back to the Vedic period (Subedi \& Poudel, 2005). J.P.B. Singh was recognized to the first person who introduced the geography subject in the school curriculum in 1901. The government of Nepal has considered the importance of teaching geography either as an optional subject from school to university levels or geographic aspect are taught in social studies as a compulsory subject after the recommendation of National Education Commission in 1992 and the National Curriculum Framework 2006 with the amendment 2014 (Khatiwada, 2019). Curriculum Development Center (CDC) has prepared a curriculum of school-level geography subject based on this framework. The curriculum covers different themes, such as physical geography, regional geography, human geography, economic geography, and practical geography (Khatiwada, 2019).

Geography found its place in the school curricula in Nepal with the establishment of School Leaving Certificate (SLC) Board in 1934. Over the last 71 years, it has traversed several ups and downs with intricate itinerary in the secondary curriculum. Since the establishment of the board till1951, it was offered as one out of eight papers. In the SLC examination of the total scores, it carried a weight of 12.5 present. Between 1951 to the implementation of National Education System Plan (NESP) 1971, geography occupied its place as optional paper and competed with history. Of the total score of 900 with nine papers it carried out 11.1 percent weight in SLC. In addition, during these years, geography could also be taken as an extra-optional subject. With the introduction of NESP, geography become compulsory subject in the secondary school. But its overall weight reduced to 5.6 percent and it was treated within the umbrella of social studies. This provision did not last long and since 1981 the subject offering in the secondary level were reorganized. The total score of SLC was dropped down to 700 . While doing so geography was marginalized as one of the subject in optional category competing with general science and math. As a result, many genus students faced with difficult choice opted science or math and geography was forced to be as a least favored subject. However, when the total score of SLC was revised to 800 in the middle of 1990 s, social studies was introduced as a compulsory subject. Of the total contents of social studies, the share of geography of SLC curriculum contains at about 3.3 percent only. These changes in the offering and weight of the subject in the secondary level curriculum directly affected the entry of students in geography at the higher education (Subedi \& Poudel, 2006). This reveals that the challenges of geography discipline in Nepal in general and university level in particular. They can be classified in various ways: for example, curricular issues, disciplinary issues, policy issues and market integration issues. 
Curricular Issues: The geography curricula at any level have been designed to provide knowledge of geographical, cultural, economic and human aspects of the world. This knowledge comprises through different branches of geography such as physical, human, regional, tools and techniques and field study (Khatiwada, 2019). The curriculum also provides comprehensive knowledge about the geographical and cultural diversity of Nepal. For this purpose, the geography discipline requires an array of understanding and abilities regarding to fulfill national as well as personal needs of learners. However, Faculty of Education (FoE) and Faculty of Humanities and Social Sciences (FoHSS) both have been offering the curriculum of geography for Bachelors and Master levels. But we can't justify its validity why we need two separate institutions for the same purpose. This question is frequently asked of us, but we answered regarding this question is not satisfactory. Only we try to reply that the terms of reference (TOR) of FoHSS is to produce geographical knowledge and the FoE gives emphases on the pedagogy of teaching geography in the classroom. But we do not know what the reality is? This seems to be the first curricular challenge. For this purpose, respondent's views are very important to reveal curricular issues.

More than 24 percent respondent emphasized that the ability to make the curriculum relative to time and the manpower, has considered major challenges to declining job opportunities. Similarly, 40 percent have considered that courses have not emphasized to practical and technical fields such as GIS, tourism, climate change and water resources. About 20 percent highlighted to the curriculum change and 16 percent of time allocation. As a result, number of students who majoring geography subject have been decreasing year-by-year. Table 1 reveals that the causes of students declining in geography subject. The result shows that more than 34 percent respondents reported that there is a declining trend in student enrollment in school level. It is mainly due to school as a source of student in geography in higher level, but the geography subject is taught as an optional subject at school level. It is followed by the lack of job market in the second (30\%), lack of proper policy for geography education $(24 \%)$ and lack of quality education $(6 \%)$ and curriculum $(6 \%)$.

Table 1: Causes of student declining in geography subject

\begin{tabular}{l|c|c}
\hline Causes & No. of respondent & Percentage \\
\hline No clear policy of nation & 12 & 24 \\
No good curriculum & 3 & 6 \\
No Geography in school level & 17 & 34 \\
No job market & 15 & 30 \\
No quality education & 3 & 6 \\
\hline Total & 50 & 100 \\
\hline
\end{tabular}

Source: Field Survey, 2013 
Table 2 shows the number of student enrollment in geography in the secondary level since the years of 2003 to 2014 .

Table 2: Students enrollments in geography subject at secondary level

\begin{tabular}{c|c|c}
\hline Year & Geography Students & Total Students \\
\hline 2003 & 17865 & NA \\
2004 & 17547 & NA \\
2005 & 17273 & NA \\
2006 & 17976 & NA \\
2007 & 17637 & 307010 \\
2008 & 16775 & 342632 \\
2009 & 15917 & 384146 \\
2010 & 14768 & 497759 \\
2011 & 13851 & 419049 \\
2012 & 12696 & 404934 \\
\hline
\end{tabular}

Source: Examination section SLC Board, MOE, Sanothimi, Bhaktapur, 2013

Table 3 indicates that the downward moving trends in the enrollment of students in geography subject in the higher secondary level.

Table 3: Students enrollments in geography subject at higher-secondary level

\begin{tabular}{c|c|c}
\hline Year & Geography Students & Total Students \\
\hline 2003 & 831 & 101354 \\
2004 & 914 & 117428 \\
2005 & 1044 & 155471 \\
2006 & 1371 & 200482 \\
2007 & 1578 & 248871 \\
2008 & 1842 & 338987 \\
2009 & 2045 & 438066 \\
2010 & 2043 & 525095 \\
2011 & 1594 & 566556 \\
2012 & 998 & 544457 \\
\hline
\end{tabular}

Source: Examination section HSEB Board, MOE, Sanothimi, Bhaktapur, 2013

The result reveals that out of total 404934 students enrolled in higher-secondary level, only 12696 students $(3.13 \%)$ were enrolled in geography. This figure clearly indicates that the grass-root of the geography subject at school level is very poor in the years of 2003-2012 SLC examination. The HSEB aims to produce intermediate manpower for national development. The result has also indicated as the same trends of SLC for student enrollment in the geography subject. There were only 998 students enrolled in the year 2012 . 
Table 4 presents the trend of student enrollment in geography in bachelor level from 2008 to 2012. The table shows the declining trend of student's enrollment in bachelor level from first year to third year.

Table 4: Students Enrollment in Bachelor Level in Geography

\begin{tabular}{c|c|c|c}
\hline Year & Fist & Second & Third \\
\hline 2008 & 173 & NA & NA \\
2009 & 222 & 124 & NA \\
2010 & 127 & 158 & 115 \\
2011 & NA & 100 & 136 \\
2012 & NA & NA & 82 \\
\hline
\end{tabular}

Source: Examination section of T.U., Balkhu, 2013

Table 5 shows the student's enrollment in both Mater of Arts (M.A.) and Master in Education (M. Ed.) programs. Masters level programs are running in both M.Ed. in Kirtipur and M.A. in geography in the University Campus, Kirtipur and P.N. Campus Pokhara. The number of students is relatively high in M.A. as compared to the M. Ed. program. There is crisis of students in the M. Ed level. At present, there is a provision that student can enrolled in M.A. geography from any subject having graduate degree.

Table 5: Students Enrollment in Masters Level in Geography

\begin{tabular}{ccc}
\hline Year & Master in arts (M.A.) & Master in Education (M. Ed.) \\
\hline 2003 & 90 & 20 \\
2004 & 76 & 18 \\
2005 & 78 & 8 \\
2006 & 111 & 3 \\
2007 & 148 & 4 \\
2008 & 132 & 6 \\
2009 & 91 & 6 \\
2010 & 81 & 5 \\
2011 & 111 & 5 \\
2012 & 144 & 15 \\
\hline
\end{tabular}

Source: Examination section of T.U., Balkhu, 2013 
Disciplinary Weakness: Disciplinary weakness is one of the factors showing the status of geography. They can be categorized into lack of advocacy (24\%), lack of publicity $(16 \%)$, lack of resources $(28 \%)$ and lack of proper government policy $(32 \%)$. The majority of respondents $(68 \%)$ reported that institutional factor is more responsible for the number of student declining in the geography subject as compared to individual factor (teacher 32\%). As reported, institutional factor includes national educational policy, FoE policy and Tribhuvan University policy towards improving geography subject. They have also reported that the importance of geography is not clearly understood by different stakeholders such as public, media, leader and society.

Policy Issues: Teacher's activities and practices are not getting together, but they are divided and fragmented. Table 6 presents the different policy issues related to student's enrollment in Geography subject in different levels of education. Majority of respondents (60 percent) perceived that there is lack of proper national policy and educational policy for the development of geography discipline. About 24 percent observed T.U. policy mistake and 16 percent perceived that geography policy maker are responsible for declining student in geography discipline.

Table 6: Respondent's views on different policies

\begin{tabular}{l|c|c}
\hline Policies & No of respondents & Percentage \\
\hline National Policy & 17 & 34 \\
Educational Policy & 13 & 26 \\
T.U. Policy & 12 & 24 \\
Policy of subject committee & 8 & 16 \\
\hline Total & 50 & 100 \\
\hline
\end{tabular}

Source: Field survey, 2013

Way forward to improve enrollment in Geography: Table 7 presents the way outs of improvements of geography subject. About 30 percent respondents perceived that geography should be made compulsory subject in school level to increase student's enrollment in this subject. This is a very good way to save the discipline. Likewise, 24 percent observed that knowing geography is an identity of nation or it helps to increase national identity. Therefore, plenty of space should be given to its improvement. 
Tara Prasad Awasthi / Challenges of Geography in Nepal

Table 7: Way forwards to improve geography subject

\begin{tabular}{l|c|c}
\hline Way outs & Respondents & Percentage \\
\hline Compulsory in school & 15 & 30 \\
Job Guarantee (Market) & 6 & 12 \\
Nation's education goal & 4 & 8 \\
Identity of Nation & 12 & 24 \\
Importance of Geography & 13 & 26 \\
\hline Total & 50 & 100 \\
\hline
\end{tabular}

Source: Field survey, 2013

\section{Conclusion}

The content and the weightage of geography subject in the SLC curriculum have been changing and remained at about 3.3 percent at present. Geography is offered as one of the optional subjects in both the school and university levels. The knowledge of geography is necessary for each and every citizen for the national development. However, the enrollment of students in geography is very limited and has been declining day-byday due to various factors like lack of proper government policy, lack of advocacy of the subject and others. The change in the offering and weightage of the subject in the secondary level curriculum is one of the responsible factors that directly affected the entry of students in geography at the higher education. Secure job market is one of the factors to improve enrollment in different level of education. For this, curriculum should be revised considering present need of the job market. Likewise, geography should be made compulsory subjects in school level curriculum for the improvement of enrollment in the higher education.

\section{References}

Adhikari, J. (2003). Geographical education and studies in Nepal. (Unpublished Seminar Paper). Kathmandu. Pp.1-35.

Amatya, S. L. (1974). Geography in Nepal. In Prayag Raj Sharma (Ed.), Social science in Nepal. Kathmandu: Institute of Nepal and Asian studies. pp. 1-17.

Awasthi, T. P. (2013). Geography study in crisis. A Mini Research Report Submitted to Research Division Rectors office Tribhuvan University, Kirtipur.

Jnawali, D. (2001). Nepalma bhoogol shiksha: pathyakram, pathyapustak ra shikshan (Geography Education in Nepal: curriculum, textbooks and teaching). 
Educational Innovation (a publication on educational issue). Kathmandu: Center for Educational Innovation and Research (CEIR).vol.1 (1), pp.117-129.

Khatiwada, S. P. (2019). Status and barriers of classroom-based student assessment practices in geography at secondary level in Nepal. Manuscript submitted for publication.

Kitchen, R. \& Tate, N. J. (2000). Conduction research in human geography: Theory methodology and practice. London

Koirala, H. L. (2008).Geography in crisis: Is geography in Nepal an exception? In Bhim Prasad Subedi (Ed.), The Geographical Journal of Nepal. Kathmandu: Central Department of Geography, Pp31-44.

Livingston, D. (1992). A brief history of geography. In Rogers, A., Vile, H. and Goudie, A. (Eds.), The Students Companion to Geography. Oxford: Blackwell.

Panday, R. K. (1998). Pioneers of Nepalese geography: Geography and Geographers in Nepal. Kathmandu: Center for Nepalese Geography.

Subedi B. P. (2005). A glimpse of geographic research in Nepal: Review and reflection. In Subedi, B.P. and Poudel P.C. (Eds.), Geography and Geographers Work in Nepal: Reflections on Mountain Environment and Human Activities. Kathmandu: Central Department of Geography, Nepal geographical society and NCCR north-south, pp. 85-103.

Subedi, B. P. \& Joshi. B. D. (1997). About geography in Nepal: An outline for discussion. In Prem K. Katry ed.), Social Sciences in Nepal: Some Thoughts and Search for Direction. Kathmandu: Center for Nepal and Asian Studies. pp. 90-112.

Subedi B. P. \& Poudel, P. C. (2006) Nepalese geographers meet in Pokhara: an introduction. In Subedi, B.P. Poudel P.C. and Poudel K.P. (Eds.), Geography in Nepal: Mountain Environment and Human Activities. Kathmandu: Nepal Geographical Society, Central Department on Geography Nepal Geography and NCCR North-South, pp1-9. 